\title{
ANALISA ALGORITMA APRIORI DENGAN ASSOCIATION RULE UNTUK REKOMENDASI PROMOSI PRODUK ELEKTRONIK DI TOKO UD SURYA KISARAN
}

\author{
Yustika Margolang1, Fauriatun Helmiah M.kom ${ }^{2 *}$, Mardalius M.kom ${ }^{3}$ \\ ${ }^{1}$ Mahasiswa Prodi Sistem Informasi, STMIK Royal \\ ${ }^{2}$ Prodi Manajemen Informatika, STMIK Royal \\ ${ }^{3}$ Prodi Sistem Informasi, STMIK Royal \\ "email: fauriatunh@gmail.com
}

\begin{abstract}
Data Mining is a term used to describe the processes in each itemset to be able to find the results of each item. Analysis is used to determine the promotion of electronic products, namely the a priori algorithm association rules, therefore UD Surya Elektronik Shop for increasing sales results must have other strategies to be able to improve the sales system. One way is to determine the goods to be promoted to consumers. The collection of sales data that is owned can actually be processed using data mining to see customer buying patterns, with data mining for large data it will not be wasted and can be useful so that it can provide benefits to the company. In this study, the data processing uses the Apriori Algorithm, which is a data mining method that aims to find association patterns based on purchasing patterns made by consumers, so that it can be seen which items are often purchased simultaneously.
\end{abstract}

Kata Kunci : Data Mining;Apriori Algorithms;Product Promotion

\begin{abstract}
Abstrak: Data Mining adalah suatu istilah yang digunakan untuk menguraikan proses-proses di setiap itemset untuk dapat menemukan hasil setiap item-item nya, Analisa yang digunakan untuk menentukan promosi produk-produk elektronik yaitu dengan aturan asosiasi algoritma apriori, oleh karena itu Toko UD Surya Elektronik untuk meningkatkan hasil penjualan maka harus memiliki strategi lain untuk dapat meningkatkan sistem penjualannya. Salah satunya adalah dengan menentukan barang yang akan dipromosikan kepada konsumen. Kumpulan data penjualan yang dimiliki sebenarnya dapat diolah menggunakan data mining untuk melihat pola pembelian pelanggan, dengan data mining untuk data yang besar tidak akan terbuang begitu saja dan dapat bermanfaat sehingga dapat memberikan keuntungan kepada perusahaan. Pada penelitian ini, proses pengolahan data menggunakan Algoritma Apriori yang merupakan salah satu metode data mining yang bertujuan untuk mencari pola assosiasi berdasarkan pola pembelian yang dilakukan oleh konsumen, sehingga bisa diketahui item-item barang apa saja yang sering dibeli secara bersamaan.
\end{abstract}

Kata Kunci : Data Mining;Algoritma Apriori;Promosi Produk. 
Available online at http:// jurnal.stmikroyal.ac.id/index.php/j-com

\section{PENDAHULUAN}

Sistem informasi berbasis komputer setiap tahunnya mengalami perkembangan yang sangat pesat hampir di semua bidang dan banyak sekali orang yang menggunakan teknologi canggih dari zaman ke zaman selalu banyak perubahan yang telah terjadi. Teknologi mempunyai peranan yang sangat penting untuk menunjang kemudahan, sudah banyak teknologi yang diciptakan oleh manusia untuk mewujudkan keinginan manusia itu sendiri, teknologi sebagai salah satu peranan penting bagi semua manusia dan juga merupakan sebuah alat bantu yang berguna bagi manusia karena dengan adanya teknologi masyarakat dari berbagai usia biasa menggunakannya sesuai dengan kebutuhan yang di inginkan,

Teknologi yang ada di zaman modern saat ini sangat bermanfaat bagi masyarakat terutama untuk mendapatkan informasi-informasi baik dari luar maupun dalam negeri, begitu pesatnya perkembangan teknologi didunia sehingga setiap tahunnya banyak terjadi update tentang teknologi, yang juga berimbas kepada kemajuan teknologi pada bidang elektronik. Sistem informasi dapat dipahami sebagai sekumpulan subsistem yang saling berkaitan dalam membentuk satu kesatuan, saling berintegrasi dan saling membantu antara bagian satu dengan yang lainnya dengan caracara yang telah ditentukan untuk melakukan fungsi pengolahan data, menerima (input) berupa data-data [1].

Elektronik merupakan salah satu kebutuhan yang sangat mendukung di kalangan masyarakat, berdasarkan data yang dirilis ketua umum gabungan pengusaha elektronik pada tahun 2018 penurunan penjualan elektronik turun 10\% setiap tahunnya. Daya beli masyarakat terhadap produk elektronik kini menjadi pesat contohnya adalah pembelian produk elektronik seperti televisi, DVD, kulkas, AC, kipas angin dan lainnya. Untuk menunjang keberhasilan sebuah perusahaan dalam mencapai tujuan itu sangat dipengaruhi oleh kemampuan perusahaan dalam memasarkan produknya dengan harga yang menguntungkan pada tingkat kualitas yang diharapkan, akan mampu mengatasi tantangan dari para pesaing terutama dalam bidang pemasaran [2]. Keberhasilan strategi pemasaran yang sesuai dengan kondisi pasar yang dihadapi agar produk yang dipasarkan dapat berhasil maka salah satu hal yang dilakukan dengan membuat promosi pada produk elektronik.

Dalam hal penentuan promosi produk elektronik yang ada di toko UD Surya Elektronik, penjual sering kali salah dalam menentukan promosi barang karena tidak sesuai dengan kebutuhan yang di inginkan konsumen, sehingga barang yang di promosikan sebelumnya tidak di jangkau karena tidak sesuai dengan kebutuhan rumah tangga yang di perlukan konsumen, sehingga barang tersebut terkadang hanya menjadi pajangan yang cukup lama dan biasa terjadi kerugian di perusahaan itu sendiri. Ketersediaan database mengenai catatan transaksi pembelian para pelanggan suatu supermarket atau tempat lain, telah mendorong perkembangan teknik-teknik secara otomatis menemukan asosiasi produk atau item-item yang tersimpan dalam database tersebut [1]-[3].

Sama hal nya lokasi pengamatan yang peneliti lakukan di toko UD Surya Elektronik, perusahaan memerlukan strategi yang baik untuk meningkatkan daya jual yang dimiliki untuk menciptakan peningkatan pendapatan sesuai dengan rencana yang di atur oleh pemilik toko, Semakin banyak permintaan masyarakat akan produk-produk 
yang di butuhkan di dalam sebuah rumah dengan adanya promosi produk elektronik sehingga dapat mempengaruhi masyarakat untuk datang ke toko tersebut. Salah satu upaya yang ditempuh oleh perusahaan dalam meningkatkan volume penjualan yaitu dengan menentukan produk mana saja yang cocok dijadikan promosi dan penyusunan pola untuk mendapatkan hasil yang sesuai dengan menggunakan metode algoritma apriori.

Algoritma apriori merupakan salah satu jenis algoritma yang ada pada data mining yang memakai aturan asosiasi [4], [5]. Dalam mencari frekuensi untuk menentukan keterkaitan itemset-itemset dapat diolah dari kumpulan data yang sudah ditentukan minimum support dan confidence. Tujuan dari penelitian yaitu untuk merancang sebuah sistem yang baik dalam merekomendasikan promosi produk di toko UD Surya Elektronik Kisaran dalam meningkatkan efektifitas dan efesiensi, untuk mengetahui pola pembelian produk yang akan sering dibeli konsumen secara bersamaan, untuk merancang sebuah sistem menggunakan algoritma apriori dengan association rule terhadap rekomendasi promo produk di toko UD Surya Elektronik Kisaran.

\section{METODE}

Data Mining didefinisikan sebagai aktifitas menggali data dari kumpulan big data untuk meenggali sebuah informasi yang memiliki keunggulan tersendiri sesuai kebutuhan. Association rule dalam pembentukan sebuah bola disebut dengan "if-then" atau "jika-maka" merupakan suatu istilah yang sering digunakan dalam proses algoritma apriori untuk mendapatkan hasil pola pembelian dari hasil transaksi penjualan yang telah dilakukan. Algoritma apriori merupakan salah satu jenis algoritma yang ada pada data mining yang memakai aturan asosiasi [4]. Dalam mencari frekuensi untuk menentukan keterkaitan itemset-itemset dapat diolah dari kumpulan data yang sudah ditentukan minimum support dan confidence.

$$
\begin{aligned}
& S=\sum(\mathbf{T x}+\mathbf{T y}) \sum \mathbf{T} \quad x \quad \mathbf{1 0 0} \% \\
& \boldsymbol{C}=\sum(\mathbf{T x}+\mathbf{T y}) \sum \mathbf{T x} \quad x \quad \mathbf{1 0 0 \%}
\end{aligned}
$$

Keterangan rumus :

$S=$ Support $\sum(T \mathrm{x}+T \mathrm{y})=$ Jumlah transaksi yang mengandung " $\mathrm{X}$ " dan " $\mathrm{Y}$ " $\sum T$ $=$ Jumlah Transaksi

$=$ Confidence $\sum(T \mathrm{x}+T \mathrm{y})=$ Jumlah transaksi yang mengandung " $\mathrm{X}$ " dan " $\mathrm{Y}$ " $\sum T \mathrm{x}=$ Jumlah Transaksi yang mengandung " $X$ "

Berikut ini beberapa sampel produk yang ada pada Toko UD Surya : 
Vol. 1 No. 2, Juli 2021, hlm. $89-94$

DOI: https://doi.org/10.33330/j-com.v2i1.1190

Available online at http:// jurnal.stmikroyal.ac.id/index.php/j-com

Tabel 1. Data Penjualan Perbulan

\begin{tabular}{|c|c|c|c|c|c|}
\hline Transaksi & Kulkas & Televisi Led & Speaker & Blender & Mesin Cuci \\
\hline $31 / 01 / 2019$ & 1 & 0 & 0 & 0 & 0 \\
\hline $28 / 02 / 2019$ & 0 & 1 & 0 & 0 & 0 \\
\hline $31 / 032019$ & 1 & 0 & 0 & 0 & 0 \\
\hline $30 / 04 / 2019$ & 0 & 1 & 0 & 0 & 0 \\
\hline $31 / 05 / 2019$ & 0 & 0 & 1 & 0 & 0 \\
\hline $30 / 06 / 2019$ & 0 & 0 & 0 & 1 & 0 \\
\hline $31 / 07 / 2019$ & 1 & 0 & 0 & 0 & 0 \\
\hline $31 / 08 / 2019$ & 0 & 1 & 0 & 0 & 0 \\
\hline $30 / 09 / 2019$ & 0 & 1 & 0 & 0 & 0 \\
\hline $31 / 10 / 2019$ & 0 & 0 & 0 & 0 & 1 \\
\hline $30 / 11 / 2019$ & 0 & 0 & 0 & 0 & 1 \\
\hline $31 / 12 / 2019$ & 0 & 1 & 0 & 0 & 0 \\
\hline JUMLAH & & & 12 & & \\
\hline
\end{tabular}

Iterasi tersebut mulai dilakukan dengan tujuan membentuk kandidat 1-Itemset dari data-data transaksi tersebut dan hitung jumlah supportnya. Cara menghitung support adalah jumlah kemunculan item dalam transaksi dibagi dengan jumlah seluruh transaski. Berikut keterangan : Jumlah transaksi yaitu 12

Rumus : $\quad$ support $(\mathrm{A})=\frac{\text { jumlah transaksi } \mathrm{A} \times 100 \%}{\text { T }}$ Total transaski

Tabel 2. Item set

\begin{tabular}{|l|l|c|c|}
\hline No & & Item set & \\
\hline 1 & Kulkas & 3 & 0,25 \\
\hline 2 & Televisi Led & 5 & 0,417 \\
\hline 3 & Speaker & 1 & 0,083 \\
\hline 4 & Blender & 1 & 0,083 \\
\hline 5 & Mesin Cuci & 2 & 0,167 \\
\hline
\end{tabular}

$\begin{array}{ll}\text { support }(\mathrm{A}) & =(3 / 12) \times 100 \%=0,25 \\ \text { support }(\mathrm{B}) & =(5 / 12) \times 100 \%=0,417 \\ \text { support }(\mathrm{C}) & =(1 / 12) \times 100 \%=0,083 \\ \text { support }(\mathrm{D}) & =(1 / 12) \times 100 \%=0,083 \\ \text { support }(\mathrm{D}) & =(2 / 12) \times 100 \%=0,167\end{array}$

Minmum support yang ditentukan minimal 0,25 selain dari nilai tersebut maka tidak dapat dinyatakan terpilih direkap data perbulan selama 12 bulan.

Tabel 3. Hasil Perhitungan terpilih

\begin{tabular}{|c|c|c|c|c|c|}
\hline No & $\mathrm{X} \rightarrow \mathrm{Y}$ & Nama Produk & support X U Y & Persentase & Keterangan \\
\hline 1 & $\mathrm{~A}$ & Kulkas & 0,25 & $25 \%$ & Lolos \\
\hline 2 & $\mathrm{C}$ & Televisi Led & 0,417 & $41 \%$ & Lolos \\
\hline
\end{tabular}


Vol. 1 No. 2, Juli 2021, hlm. 89 - 94

DOI: https://doi.org/10.33330/j-com.v2i1.1190

Available online at http:// jurnal.stmikroyal.ac.id/index.php/j-com

\section{HASIL DAN PEMBAHASAN}

Hasil yang akan diperoleh pada penelitian ini yaitu sebuah sistem dengan penerapan metode algoritma apriori dengan association ruleyang didalamnya terdapat pengolahan data promosi produk sesuai dengan hasil rekapan data perbulan mulai dari bulan januari hingga hingga desember, dengan adanya penerapan sistem ini sehingga dapat menghasilkan peningkatan hasil penjualan produk yang akan dipromosikan dan dapat memudahkan dalam pencarian produk, Implementasi sistem terhadap program yang penulis buat berdasarkan dari hasil analisa dan perancangan adalah sebagai berikut :

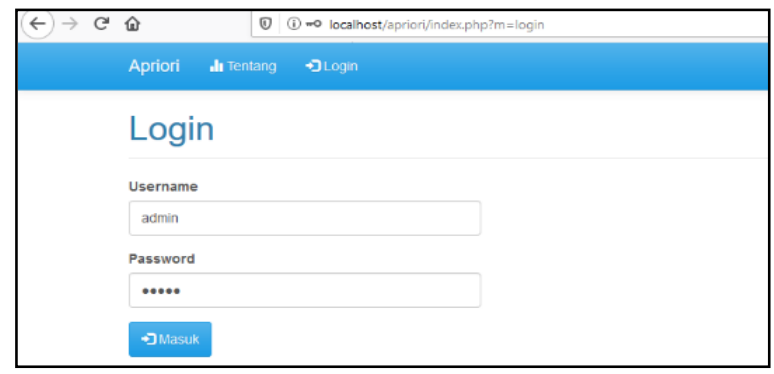

Gambar 1. Form Login

Tampilan Input dan Tampil Data Transaksi Input data transaksi berfungsi sebagai salah satu jenis data transaski dari data perbulan yang telah di rekap oleh admin dengan jumlah produk elektronik yang sering muncul secara bersamaan di dalam sistem atau penginputan data sesuai dengan hasil laporan yang telah di acc oleh atasan dari toko ud surya kisaran.

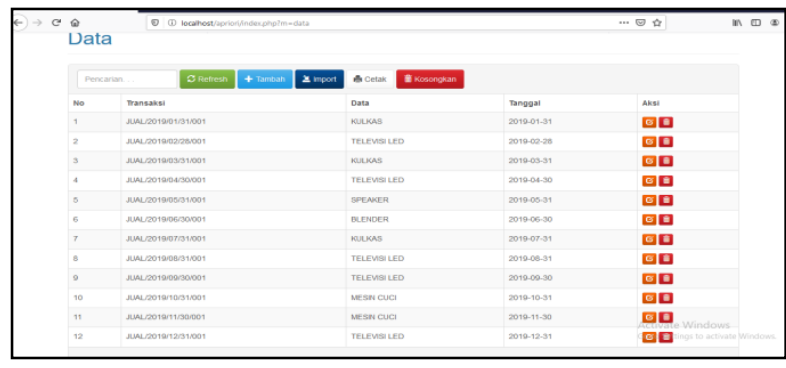

Gambar 2. Tampil Data Transaksi

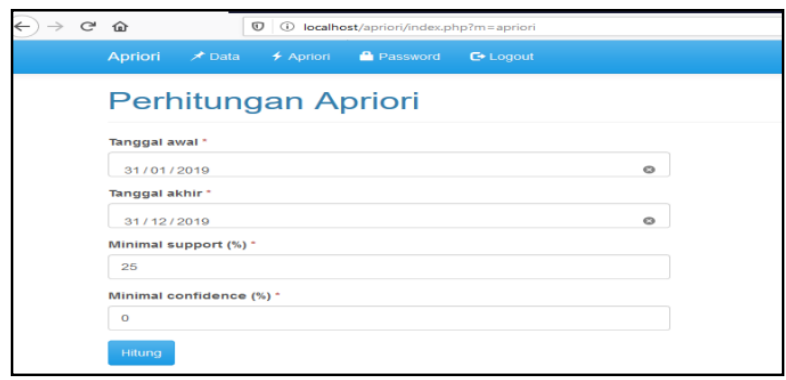

Gambar 3. Proses Perhitungan Hasil Apriori 
Vol. 1 No. 2, Juli 2021, hlm. $89-94$

DOI: https://doi.org/10.33330/j-com.v2i1.1190

Available online at http:// jurnal.stmikroyal.ac.id/index.php/j-com

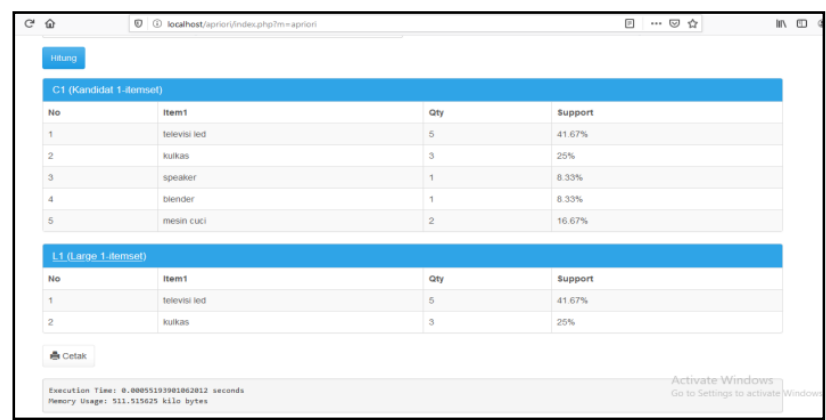

Gambar 4. Proses Algoritma Apriori

\section{SIMPULAN}

Algortima apriori dapat mencari aturan association dalam bentuk pola berdasarkan transaksi terbanyak kemudian berdasarkan hasil dari perhitungan algoritma apriori dapat mempermudah untuk menentukan promosi produk di toko UD Surya dan algoritma apriori terhadap data pola penyusunan produk yang dapat menyajikan sebuah aplikasi yang berkualitas, berdasarkan sistem yang telah dibangun dengan menggunakan aplikasi PHP My Admin dengan Algoritma Apriori sistem ini mampu menentukan aturan asosias pada data transaksi penjualan produk perbulan untuk mendapatkan pola rekomendasi promosi produk sehingga dapat meningkatkan target pasar penjualan pada toko UD Surya.

\section{DAFTAR PUSTAKA}

[1] Y. Heriyanto, "Perancangan Sistem Informasi Rental Mobil Berbasis Web Pada PT.APM Rent Car," J. Intra-Tech, vol. 2, no. 2, pp. 64-77, 2018.

[2] C.Pradeepkumar and S.Loganathan, "Penerapan Metode Asosiasi Menggunakan Algoritma Apriori Pada Aplikasi Pola Belanja Konsumen ( Studi Kasus Toko Buku Gramedia Bintaro )," Int. J. Sci. Eng. Res. (IJOSER), vol. 3, no. 4, pp. 120-127, 2015, [Online]. Available: http://journal.uinjkt.ac.id/index.php/ti/article/view/5602/3619.

[3] Verawati and P. D. Liksha, "Aplikasi Akuntansi Pengolahan Data Jasa Service," J. Sist. Inf. Akunt., vol. 1, no. 1, p. 3, 2018.

[4] A. A. Christyan Putra, H. Haryanto, and E. Dolphina, "Implementasi Metode Association Rule Mining Dengan Algoritma Apriori Untuk Rekomendasi Promo Barang," CSRID (Computer Sci. Res. Its Dev. Journal), vol. 10, no. 2, p. 93, 2021, doi: 10.22303/csrid.10.2.2018.90-100.

[5] D. Sukrianto, "Penerapan Teknologi Barcode pada Pengolahan Data Pembayaran Sumbangan Pembinaan Pendidikan (SPP)," Intra-Tech, vol. 1, no. 2, pp. 18-27, 2017. 